\title{
PENDIDIKAN AGAMA ISLAM DAN ANTISIPASI RADIKALISME KEAGAMAAN
}

\author{
Wahyudin Noor \\ IAIN Syaikh Abdurrahman Siddik Bangka Belitung, Indonesia \\ wahyudinoor@gmail.com
}

\begin{abstract}
Abstrak: This paper is structured and aims, first, to describe the implementation of Islamic Religious Education in high schools in the Pangkalpinang City, and second, to reveal the implications of the implementation of Islamic religious education in an effort to anticipate the strengthening of religious radicalism in high school students in the Pangkal Pinang City. The results can be explained as follows: 1) the implementation of Islamic religious education in high schools in the Pangkalpinang City generally aims to increase knowledge, convey the teachings and rules of Islamic religion, change morals and foster students according to religious rules and improve practices of worship that have not been good. In terms of material, the books used to refer to books published by the Ministry of Education and Culture and some teachers also complete them with other published books. As for the material presented, the teacher occasionally links, for example, the theory of Islamic education with cultural traditions. 2) Implications of the implementation of Islamic religious education in terms of objectives namely how to minimize the strengthening of the understanding of religious radicalism by studying and applying the values of togetherness, goodness, and general values between religions or certain groups; overall the contents of the study references are from official sources. On the other hand, linking Islamic religious education materials with the culture of society is something that needs to be done to anticipate the spread of religious radicalism in schools; from the method side, there is a reduction in indoctrination patterns.
\end{abstract}

Kata Kunci: Islamic religious education, Religious radicalism 


\section{A. Pendahuluan}

Pembelajaran Isu radikalisme keagamaan di sekolah menjadi tantangan baru bagi dunia pendidikan di Indonesia. Dari laporan survey yang dilakukan Lembaga Kajian Islam dan Perdamaian (LaKIP) di tahun 2010 yang lalu misalnya, hasilnya sangat mengejutkan, 48,9\% peserta didik di Jabodetabek mengungkapkan persetujuannya terhadap aksi radikal atas nama agama. ${ }^{1}$ Khusus di Bangka Belitung misalnya, hampir tidak pernah ditemukan konflik berlatar belakang agama. Kendatipun demikian, di akhir Agustus 2018, fenomena radikalisme emosi keagamaan telah jadi viral dalam kasus ujaran kebencian dan penghinaan yang dilakukan tiga orang pemuda, - dua di antaranya masih berstatus pelajar, terhadap Presiden Joko Widodo. Salah satu isi penghinaannya, disebutkan bahwa Presiden Joko Widodo adalah sebagai seorang kafir. ${ }^{2}$

Dari kasus di atas, setidaknya bisa memberikan kesadaran kepada guru, khususnya guru Pendidikan Agama Islam (PAI), bahwa ada potensi bahaya yang sedang mengintai para peserta didiknya. Menurut David R. Krathwohl, ${ }^{3}$ penerimaan seseorang terhadap suatu nilai menjadi tahap awal dari lima tahap ranah afektif. Dan penilaian seseorang terhadap sesuatu adalah tahap ketiga dari lima ranah tersebut. Artinya, jika persetujuan peserta didik terhadap perbuatan radikal dan penilaian 'kafir' terhadap orang lain yang memang tidak sepaham itu dibiarkan, akan sangat mungkin orang atau peserta didik tersebut mempunyai sikap dan kepribadian yang rentan berbuat kekerasan demi meraih kehendak dan tujuan. Atas dasar itu, radikalisme pada tahap pemikiran telah mendapat dukungan dari kalangan sekolah.

Istilah radikalisme dimaknai sebagai faham politik kenegaraan yang menghendaki adanya perubahan dan atau perombakan skala besar sebagai jalan

\footnotetext{
1 Survey ini dilakukan pada bulan Oktober 2010 sampai Januari 2011, di 10 kota di Jabodetabek. Penelitian ini dilakukan di 100 sekolah tingkat SMP dan 100 sekolah tingkat SMA. Penelitian ini menggunakan metode wawancara tatap muka dengan panduan kuesioner dan penarikan sampel acak. Batas error sampling kurang lebih 3,6\% untuk guru Pendidikan Agama Islam (PAI) dan 3,1\% untuk pelajar. Sumber: www.swattonline.com/2011/04/lakip-pemerintah-harus-tinjau-kembali-pendidikan-agama-islam_/

2 Bangka Pos, Ini Alasan Kepolisian Tak Tahan Pemuda Balunijuk yang Menghina Presiden Jokowi, bangka.tribunnews.com., diakses tanggal 14 September 2018

${ }^{3}$ Lima tahapan sikap: 1) Penerimaan (receiving), 2) Penanggapan (responding), 3) Penilaian (valuing), 4) Pengorganisasian (organization), dan 5) Karakterisasi dengan nilai atau kompleks nilai (characterization by a value or value complex). David R. Krathwohl, Taxonomy of Educational Objectives: Handbook II, Affective Domain (New York: David McKay, 1964), hlm. 55.
} 
mencapai taraf kemajuan. ${ }^{4}$ Radikalisme Islam merupakan gerakan yang berpandangan kolot dan sering menggunakan kekerasan dalam mengajarkan keyakinan mereka. ${ }^{5} \mathrm{Al}-$ Asymawi pilihan istilahnya menggunakan ekstrimisme, yaitu kelompok yang berniat mengambil kekuasaan dengan menggunakan isu agama. ${ }^{6}$ Demikian halnya Al-Jabiri juga menggunakan ektrimisme sebagai istilah untuk melukiskan kelompok-kelompok Islam radikal. ${ }^{7}$ Kendatipun demikian, radikalisme sejatinya tidak identik kekerasan dan selalu berkonotasi negatif. ${ }^{8}$ Jika sekedar ditataran pemahaman, ini tentu tidak terlalu menjadi masalah. Namun demikian, ketika radikalisme pemahaman mengalami perubahan menjadi tindakan praksis, maka radikalisme ini akan mengarah kepada tindakan yang mengakibatkan kerusakan dan anarkhis.

Pada konteks persinggungan antara peserta didik dengan faham radikalisme keagamaan tentu bukan sesuatu yang muncul sendiri secara tiba-tiba di tengah-tengah sekolah. Radikalisme itu sangat mungkin muncul karena ada proses komunikasi dengan sel-sel radikal di luar sekolah. Dari sudut ini, pihak sekolah setidaknya perlu melakukan peningkatan kemampuan untuk deteksi dini (early warning) para peserta didik yang mulai 'menyimpang' dari keumuman paham keislaman yang ada. ${ }^{9}$

Khusus guru pendidikan agama Islam, di samping perlu mengenali potensi munculnya radikalisme keagamaan dari peserta didik, guru pendidikan agama Islam juga sudah saatnya perlu membekali diri dengan pengetahuan dan pemahaman yang luas serta berbasis lintas mazhab dan keyakinan, sehingga nantinya diharapkan mampu

${ }^{4}$ Pius A. Partanto dan M. Dahlan al-Barry, Kamus Ilmiah Populer (Surabaya: Arkola, 1994), hlm. 648; Menurut Hasan Shadily, radikal berasal dari bahasa Latin, radicalis yang berarti akar suatu ikhwal. Lih. Hasan Shadily, Ensiklopedi Indonesia, (Jakarta: Ichtiar Baru-Van Hoeve, 1984), hlm. 2826; Dalam kamus bahasa Indonesia modern, radikal berarti tak ada undang-undang, tata tertib dan pemerintahan, kekacau-balauan. Lih. Muhammad Ali, Kamus Babasa Indonesia Modern (Jakarta: tp, tt), hlm. 10; Sartono Kartodirdjo mendefinisikan istilah radikalisme untuk menggambarkan gerakan protes petani yazng menggunakan simbol agama dalam menolak seluruh aturan dan tatanan yang ada. Kata radikal digunakan sebagai indikator sikap penolakan total terhadap seluruh kondisi yang sedang berlangsung. Lih. Kartono Kartodirdja, "Ratu Adil", Sinar Harapan, Jakarta, 1992, hlm. 5

${ }^{5}$ Harun Nasution, Islam Rasional (Bandung: Mizan, 1995), hlm. 124.

${ }^{6}$ Muhammad Said al-Asymawi, Al-Islam al-Siyasi (Kairo: Sina li al-Nasyr, 1987), hlm. 66.

${ }^{7}$ Muhammad Abid al_jabiri, Agama, Negara dan Penerapan Syari'ah (Yogyakarta: Pustaka Pelajar, 2001), hlm. 139.

${ }^{8}$ Lih. Martin van Bruinessen, NU: Tradisi, Relasi-relasi Kuasa, Pencarian Wacana Baru, terj. Farid Wajidi (Yogyakarta: LkiS, 1994), hlm. 105-106.

9 Abu Rokhmad, "Radikalisme Islam dan Upaya Deradikalisasi Paham Radikal", Walisongo, Vol. 20 No. 1 (Mei 2012), hlm. 82. 
mengisi sekaligus memenuhi kehausan intelektual dan spiritual peserta didik dalam pelaksanaan pembelajarannya dengan pencerahan yang menyejukkan dan mendamaikan. Dari sini dapat dikatakan bahwa cita rasa dan watak keberagamaan peserta didik tidak terlepas dari bagaimana agama itu dikenalkan, dipersepsikan, dan diwacanakan.

Berangkat dari penjelasan di atas, secara metodologis pelaksanaan pendidikan agama Islam hendaknya menuntut adanya situasi yang memungkinkan tersentuhnya "perasaan beragama" (religious mind) yang menuntun peserta didik untuk bergaul dengan orang lain secara arif dan bermartabat. Situasi sebagaimana dimaksud tentunya membutuhkan proses pembelajaran yang bukan sekedar pemahaman agama pada level teori tapi juga pada level praktek di mana nilai-nilai agama akan berdialog dan bernegosiasi dengan realitas kehidupan. Dari sisi proses, pembelajaran diarahkan pada upaya mendorong peserta didik dan memberikan kesempatan kepadanya untuk memperoleh dan mengembangkan keterampilan hidup (life skill) berdasarkan nilainilai agamanya melalui pengalaman. Pengalaman itulah yang pada akhirnya menjadi titik tolak proses selanjutnya.

Dengan menetapkan aktualisasi pelaksanaan pendidikan agama Islam di SMA di Kota Pangkalpinang, khususnya dalam mengantisipasi radikalisme keagamaan di sekolah sebagai objek penelitian, menarik jika fenomena tersebut kemudian diangkat dalam sebuah kerja penelitian. Hal itu dimaksudkan, selain untuk mengetahui lebih jauh tentang aktualisasi pelaksanaan pendidikan agama Islam di SMA di Kota Pangkalpinang — termasuk upayanya mengantisipasi terpaparnya paham radikalisme keagamaan pada peserta didik di dalamnya_-juga sekaligus sebagai upaya memberikan kontribusi akademik yang bersifat teoretis praktis tentang fenomena sosial keagamaan di lingkungan sekolah.

Alasan dipilihnya SMA di Kota Pangkalpinang sebagai tempat penelitian, pertama, SMA di Kota Pangkalpinang merupakan representasi dari sekolah umum yang cenderung terbuka, khususnya terhadap model pengembangan dakwah dan pembelajaran keagamaan berciri khas Timur Tengah, harfiah dan bernuansa Arab pada beberapa istilah yang digunakannya; kedua, para peserta didik di sekolah umum 
notabene tidak memiliki background pendidikan agama yang memadai sehingga dimungkinkan mudah terpapar dan terpengaruh oleh model-model Islam harfiah yang diajarkan oleh guru atau ustadz mereka.

\section{B. Metodologi}

Jika ditinjau dari segi tujuannya, penelitian ini termasuk jenis penelitian deskriptif kualitatif, yaitu memberikan gambaran tentang implikasi pelaksanaan pendidikan agama Islam terhadap antisipasi radikalisme keagamaan di sekolah. ${ }^{10}$ Penelitian ini termasuk penelitian lapangan (Field Research), yaitu penelitian langsung terjun ke lokasi yang telah ditentukan. ${ }^{11}$ Penelitian ini juga disebut studi kasus (Case Study) yaitu penelitian yang mendalam mengenai kasus tertentu yang hasilnya merupakan gambaran lengkap dan terorganisir mengenai kasus tersebut. Dan kasus penelitian tersebut biasanya mencakup keseluruhan siklus kehidupan, atau kadang-kadang hanya meliputi segmen-segmen tertentu pada faktor-faktor kasus. ${ }^{12}$ Adapun pendekatan yang digunakan dalam penelitian ini adalah pendekatan fenomenologi. Penelitian ini dilaksanakan di tiga sekolah di Pangkalpinang, yakni SMA Negeri 1 Pangkalpinang, SMA Negeri 3 Pangkalpinang dan SMA PGRI Pangkalpinang.

Dalam penelitian ini subyek penelitian ditentukan secara purposive sampling dengan teknik jemput bola (snow ball sampling) yaitu menelusuri terus subyek yang dibutuhkan untuk menjawab pertanyaan penelitian. Adapun penelusuran terhadap subyek penelitian yang dibutuhkan adalah guru pendidikan agama Islam di tiga sekolah di Pangkalpinang, yakni SMA Negeri 1 Pangkalpinang, SMA Negeri 3 Pangkalpinang dan SMA PGRI Pangkalpinang. Subyek penelitian diharapkan akan dapat memberikan informasi sebanyak-banyaknya berkaitan dengan implikasi pelaksanaan pendidikan agama Islam terhadap antisipasi radikalisme keagamaan di sekolah.

Untuk mendapatkan data yang valid dan relevan, pengumpulan data dilakukan melalui: 1). Observasi; 2). Wawancara; dan 3). Dokumentasi. Analisis data yang

${ }^{10}$ Sigit Soehardi, Pengantar Metodologi Penelitian (Yogyakarta: Pena Persada Press, 2001), hlm. 25.

${ }^{11}$ Ibid., hlm. 179. hlm. 46 .

${ }^{12}$ Chalid Narbuko dan Abu Ahmadi, Metodolgi Penelitian, Cet. Ke-5 (Jakarta: PT. Bumi Aksara, 2003), 
digunakan menggunakan analisis data yang bersifat kualitatif dengan deskriptif analitik non statistic dengan langkah-langkah mereduksi, mendisplay dan memverifikasi data.

\section{Hasil Penelitian}

\section{Pelaksanaan Pendidikan Agama Islam}

a. Tujuan

Pelaksanaan pendidikan agama Islam yang dilakukan oleh seorang guru tentunya memiliki tujuan. Karena, jika pendidikan tidak berdasarkan atas tujuan, maka akan dapat dibayangkan seperti apa wajah pendidikan, suram dan tidak memiliki masa depan. Demikian juga halnya, pelaksanaan pendidikan agama Islam yang dilakukan di sekolah memiliki tujuan, sebagaimana dijelaskan oleh Yeni: ${ }^{13}$

Untuk menyampaikan ajaran agama Islam, menjabarkan aturan-aturan agama Islam, membina peserta didik untuk menjalin kehidupan sesuai dengan ajaran dan aturan agama Islam, serta memfasilitasi peserta didik dalam pembelajaran di sekolah. Selain itu, Kewajiban untuk berdakwah, kewajiban untuk pengabdian kepada Allah dan juga kewajiban selaku guru terhadap profesi yang sudah ada. Bahkan, bahwa setiap anak memiliki potensi dan karakter yang berbeda-beda. Maka sudah seharusnya guru untuk paham karakter yang dimiliki oleh peserta didik.

Penjelasan Yeni di atas memberikan penegasan bahwa, tujuan pelaksanaan pendidikan agama Islam di sekolah, hendaknya senantiasa dalam kerangka penyampaian ajaran dan aturan agama Islam yang memperhatikan potensi dan karakter peserta didik yang masing-masing di antaranya memiliki perbedaan.

Berbeda dengan Yeni, Nazlah, ${ }^{14}$ guru pendidikan agama Islam di SMA Negeri 3 Pangkalpinang memberikan pendapat, bahwa tujuan pelaksanaan pendidikan agama Islam sebagaimana dijelaskan:

...ingin merubah akhlak peserta didik agar lebih baik, merubah kebiasaan peserta didik melalui karakter yang ada pada diri peserta didik yang kurang baik, dan ingin merubah kebiasaan beribadah peserta didik yang belum

${ }^{13}$ Yeni, S,Pd.I, Guru Pendidikan Agama Islam di SMA Negeri 1 Pangkalpinang, Wawancara, Senin, 23 28 Agustus 2019. 
baik. Misalnya, setiap pertemuan di sekolah dan sekarang sudah ada penilaian sikap yang dapat membantu guru agar dapat melihat perkembangan dan perubahan dari karakter dan lain sebagainya dari diri peserta didik. Ini dilakukan dengan cara mengontrol sikap peserta didik sehari-hari di lingkungan sekolah, memberi nasehat kepada peserta didik, menilai kesehariaannya dan juga mengevaluasi setiap perkembangan peserta didik di sekolah.

Beberapa poin yang bisa diambil dari penjelasan Nazlah, bahwa tujuan pendidikan agama Islam tidak lain bagaimana dapat merubah akhlak, kebiasaan peserta didik dari yang menjadi baik dan dari yang baik menjadi lebih baik. Di samping itu, salah satu tujuan pelaksanaan pendidikan agama Islam juga seperti dipaparkan Nazlah, yakni melakukan perubahan kebiasaan beribadah peserta didik yang belum baik menjadi lebih baik.

b. Materi

Pendidikan agama Islam adalah pendidikan yang terencana untuk menyiapkan peserta didik dalam meyakini, memahami, manghayati, dan mengamalkan ajaran Islam melalui kegiatan bimbingan, pengajaran dan atau latihan. Bidang studi Pendidikan Agama Islam (PAI) meliputi: Akidah-Akhlaq, Qur'an-Hadis, Fiqh, dan Sejarah Kebudayaan Islam (SKI).

Dari sisi materi, pendidikan agama Islam banyak menyajikan ajaran (dogma agama) dan belum banyak menggali nilai dan perilaku ajaran agama serta aplikasi dan impilkasinya dalam kehidupan sehari-hari. Kendatipun demikian, Andalusia misalnya, guru pendidikan agama Islam di SMA PGRI Pangkalpinang, meskipun tidak terlalu sering mengaitkan materi yang terdapat dalam mata pelajaran pendidikan agama Islam dengan kehidupan sehari-hari, namun upaya tersebut juga pernah dilakukan. Hal ini sebagaimana dijelaskan Andalusia: ${ }^{15}$

Tidak sering, karena disesuaikan dengan materi yang diajarkan dan tidak semua materi bisa dikaitkan dengan budaya. Untuk masalah tradisi di materi ini tidak ada di PAI tapi di SKI ada untuk tradisi-tradisi budaya.

15 Andalusia, S,Pd.I, Guru Pendidikan Agama Islam di SMA PGRI Pangkalpinang, Wawancara, Senin, 26 Agustus 2019. 
Senada dengan Andalusia, Yeni, ${ }^{16}$ guru pendidikan agama Islam di SMA Negeri 1 Pangkalpinang juga memberikan pendapat yang sama, yakni dengan mencoba mengaitkan teori pendidikan agama Islam dengan tradisi budaya seperti program ceramah agama dengan kegiatan nganggung bersama yang merupakan kegiatan budaya masyarakat Bangka Belitung.

Dari penjelasan beberapa guru pendidikan agama Islam di atas, setidaknya memberikan gambaran bahwa guru telah berupaya mengaitkan materi-materi pendidikan agama Islam dengan beberapa praktik kehidupan dan budaya yang berkembang di masyarakat. Hal ini dilakukan, setidaknya menjadi ikhtiar meminimalisir bentuk-bentuk pemikiran dan sikap yang bertentangan dengan budaya yang ada di masyarakat.

c. Metode

Secara umum, metode pendidikan dapat diartikan sebagai semua cara yang digunakan dalam upaya mendidik. Karena pembelajaran adalah salah satu bentuk upaya mendidik, maka metode yang dimaksud disini mencakup juga metode pembelajaran, yakni metode yang dapat digunakan guru dalam menyelenggarakan kegiatan belajar mengajar.

Dalam melaksanakan pembelajaran pendidikan agama Islam, guru dapat memilih metode apa yang paling tepat untuk digunakannya. Nazlah, guru pendidikan agama Islam di SMA Negeri 3 Pangkalpinang menggunakan beberapa model dan metode dalam pembelajaran yang dilakukannya, hal ini seperti dikatakan Nazlah: ${ }^{17}$

Model yang saya gunakan Discovery, project, problem listening. Sedangkan metodenya jigsaw, peta konsep, bermain kartu, dan kepala bernomor. Saya lebih sering menggunakan ketiga model tersebut dengan mengklaborasikan beberapa metode, contohnya seperti metode jigsaw dan peta konsep.

${ }^{16}$ Yeni, S,Pd.I, Guru Pendidikan Agama Islam di SMA Negeri 1 Pangkalpinang, Wawancara, Senin, 23

${ }_{17}$ Nazlah, S,Pd.I, Guru Pendidikan Agama Islam di SMA Negeri 3 Pangkalpinang, Wawancara, Senin, 28 Agustus 2019. 
Tidak berbeda dengan Nazlah, Yeni, ${ }^{18}$ guru pendidikan agama Islam di SMA 1 Pangkalpinang juga selalu menggunakan metode yang bervariasi dalam pembelajaran yang dilakukannya, meliputi atas discovery, inquiry, project, problem listening, dan jigsaw. Namun yang lebih sering digunakan yaitu discovery dan problem listening. Sedangkan, Andalusia, ${ }^{19}$ guru pendidikan agama Islam di SMA PGRI Pangkalpinang justru lebih sering menggunakan diskusi, ceramah dan praktik.

Dari beberapa penjelasan di atas dapat disimpulkan bahwa pelaksanaan pendidikan agama Islam yang dilakukan oleh guru di sekolah telah menggunakan metode yang bervariasi. Artinya, pelaksanaan pendidikan agama Islam di sekolah tidak lagi monoton dan tradisional. Tapi sudah mulai mengadopsi metodemetode pembelajaran kontemporer yang tidak membuat peserta didik menjadi jenuh.

\section{Implikasi Pelaksanaan Pendidikan Agama Islam Terhadap Antisipasi Radikalisme Keagamaan di Sekolah}

a. Tujuan

Pelaksanaan pendidikan agama Islam di tiga sekolah di Pangkalpinang, jika dilihat dari sisi tujuan cenderung masih bersifat normatif. Artinya, pelaksanaan tersebut baru sebatas bagaimana mengajarkan agama Islam kepada peserta didik. Padahal, dalam kaitan hidup berbangsa dan bernegara, pelaksanaan pendidikan agama Islam sejatinya dapat memberikan suasana sejuk dan damai. Dengan demikian, pendidikan agama Islam yang diberikan di sekolah haruslah lebih ditekankan pada perilaku hidup beragama.

Karena itu, untuk meminimalisir penguatan dari paham radikalisme keagamaan peserta didik di sekolah, hendaknya pelaksanaan pendidikan agama Islam di sekolah tidak saja bagaimana ajaran agama diberikan, akan tetapi bagaimana nilai-nilai kebersamaan, kebaikan dan nilai-nilai umum antara agama Agustus 2019.

${ }^{18}$ Yeni, S,Pd.I, Guru Pendidikan Agama Islam di SMA Negeri 1 Pangkalpinang, Wawancara, Senin, 23

${ }^{19}$ Andalusia, S,Pd.I, Guru Pendidikan Agama Islam di SMA PGRI Pangkalpinang, Wawancara, Senin, 26 Agustus 2019. 
atau kelompok-kelompok tertentu pun kiranya dapat dikaji secara bersama dan diaplikasikan. Inilah bagian penting dari tujuan pelaksanaan pendidikan agama Islam di sekolah.

Dalam pada itu, ada adagium ushuliyah yang menyebutkan bahwa "al-umuru bi maqashidiha", maksudnya adalah setiap tindakan dan aktivitas harus berorientasi pada tujuan atau rencana yang telah ditetapkan. ${ }^{20}$ Sebagai suatu kegiatan yang terencana, pendidikan mesti memiliki kejelasan tujuan yang ingin dicapai. Sulit dibayangkan, jika ada suatu kegiatan tanpa memiliki kejelasan tujuan. Artinya, tujuan pelaksanaan pendidikan agama Islam tidak saja berhenti pada ajaran agama yang diberikan, namun juga harus ada upaya tentang bagaimana nilai-nilai kebersamaan antar yang berbeda agama dan keyakinan bisa dibina secara damai tanpa kecurigaan.

Oleh karena demikian pentingnya tujuan tersebut, tidak sedikit para ahli pendidikan merumuskan secara sungguh-sungguh. Ini bisa dimaklumi, mengingat tujuan pendidikan memang memiliki kedudukan yang sangat penting, Marimba, misalanya, menyebutkan ada empat fungsi tujuan pendidikan. Pertama, tujuan berfungsi mengakhiri usaha; kedua, fungsi dari tujuan adalah memberi nilai (sifat) pada usaha; ketiga, tujuan dapat berfungsi sebagai titik awal untuk mencapai tujuan-tujuan lainnya; dan keempat, tujuan berfungsi mengarahkan usaha. ${ }^{21}$ Pada fungsi yang disebutkan terakhir, setidaknya memberikan legitimasi bahwa pelaksanaan pendidikan agama Islam harus dapat misalnya, mengantisipasi berbagai penyebaran dari pemahaman radikalisme keagamaan yang belakangan cukup mengganggu tatanan kebangsaan.

b. Materi

Berdasarkan dokumentasi yang diperoleh, penggunaan bahan ajar yang digunakan guru pendidikan agama Islam di tiga sekolah di Pangkalpinang, bahwa bahan ajar yang digunakan adalah dalam bentuk buku yang diterbitkan oleh

\footnotetext{
${ }^{20}$ Ramayulis dan Samsul Nizar, Filsafat Pendidikan Islam; Telaah Sistem Pendidikan dan Pemikiran Para Tokohnya (Jakarta: Kalam Mulia, 2011), hlm. 117.

${ }^{21}$ Ahmad D. Marimba, Pengantar Filsafat Pendidikan Islam (Bandung: PT. Al-Ma'arif, 1962), hlm. 45-46; lihat juga Abuddin Nata, Filsafat Pendidikan Islam 1, Cet. I (Jakarta: Logos Wacana Ilmu, 1997), hlm. 45-46.
} 
Pemerintah Republik Indonesia, yakni Kementerian Pendidikan dan Kebudayaan. Hal ini menajdi penegas bahwa materi yang disajikan di buku atau yang akan disampaikan oleh guru, secara keseluruhan semua isi kajiannya telah melalui seleksi bahkan proses editing yang ketat. Artinya, seluruh materi yang ada di dalam buku cenderung banyak memuat hal-hal yang bersifat positif dalam menumbuhkan prinsip perilaku hidup beragama. Begitupun sebaliknya. Dengan demikian, di titik ini, upaya mengantisipasi penyebaran paham radikalisme kegamaan melalui materi yang terdapat di dalam buku dapat dipenuhi.

Di sisi lain, penyampaian materi-materi pendidikan agama Islam dengan budaya masyarakat yang berkembang misalnya, yang dilakukan oleh guru pendidikan agama Islam di tiga sekolah di Pangkalpinang merupakan bagian dari upaya mengintegraasikan materi-materi pendidikan agama Islam tersebut dengan materi yang memiliki hubungan semangat ukhuwah islamiyah, insaniyah dan wathoniyah menjadi hal yang niscaya dilakukan oleh guru pendidikan agama Islam dalam upayanya mengantisipasi penyebaran paham radikalisme keagamaan di sekolah.

Keadaan di atas sangatlah penting karena ajaran agama Islam sesungguhnya memiliki karakteristik di samping sebagai agama yang transenden, dogmatis tetapi juga universal dan dinamis. Sebab itu materi pendidikan agama Islam yang kontekstual sangat penting, disamping karena karakteristik agama Islam tersebut juga karena pendidikan agama Islam dihadapkan pada tantangan yang begitu kompleks. Tantangan tersebut dapat dikelompokkan ke dalam dua macam, yaitu tantangan internal dan tantangan eksternal dari pendidikan agama Islam. Tantangan internal menyangkut sisi pendidikan agama sebagai program pendidikan baik dari segi pemahaman terhadap materi pendidikan agama Islam, perancangan maupun pelaksanaan dan penyelenggaraan pendidikan agama Islam itu sendiri. Sedangkan tantangan eksternal berupa berbagai kemajuan iptek, era globalisasi di bidang informasi, perubahan sosial ekonomi dan budaya dengan segala dampaknya, termasuk paham-paham yang merusak sendi-sendi berbangsa 
dan bernegara seperti paham radikalisme keagamaan yang berlebihan dan merusak keharmonisan kehidupan beragama.

c. Metode

Dlihat dari sisi metode; penggunaan metode yang menekankan pada pendekatan student oriented dari beberapa metode yang biasa dipraktikkan guru pendidikan agama Islam di tiga sekolah di Pangkalpinang, telah memperlihatkan pengurangan terhadap pola-pola indoktrinisasi. Artinya, jika dikaitkan dengan upaya mengantisipasi penyebaran paham radikalisme keagamaan melalui aktivitas metode dalam pelaksanaan pendidikan agama Islam secara pelan dan pasti sudah mulai diminimalisir. Karena metode memiliki peran yang tidak bisa diremehkan, maka mendesain metode yang menekankan bagaimana menjadikan peserta didik aktif dan tidak sekedar mendengar dan menerima ajaran Islam, penting sebagaimana pentingnya tujuan dan materi dari pelaksanaan pendidikan agama Islam di sekolah.

Dari segi etimologi, kata metode sendiri berasal dari bahasa yunani yaitu methodos, yang bearti cara atau jalan. Dalam bahasa Inggris, kata ini ditulis method, dan bahasa Arab menerjemahkannya dengan طريقة ج طر اعق و منحج. Dalam bahasa Indonesia kata tersebut mengandung arti: "cara yang teratur dan terpikir baik-baik untuk mencapai maksud, cara kerja yang bersistem untuk memudahkan pelaksanaan suatu kegiatan guna mencapai suatu yang ditentukan. ${ }^{22}$ Dengan demikian, metode pembelajaran dalam pendidikan agama Islam di sekolah haruslah diupayakan lebih bisa aktratif dan menarik, sehingga muatannya tidak melulu bersifat indoktrinisasi tapi juga berkualitas prosesnya.

\section{Catatan Penutup}

1. Pelaksanaan Pendidikan Agama Islam

a. Tujuan pelaksanaan pendidikan agama Islam yang dilaksanakan oleh masingmasing guru pendidikan agama Islam secara umum lebih banyak bertujuan untuk menambah pengetahuan, menyampaikan ajaran dan aturan agama

\footnotetext{
22 Tinggal Purwanto, Pengantar Studi Tafsir, (Yogyakarta: Idea Press, 2011), hal. 27
} 
Islam, merubah akhlak dan membina peserta didik sesuai aturan agama serta memperbaiki praktik ibadah yang belum baik.

b. Materi pendidikan agama Islam diberikan oleh guru pendidikan agama Islam merujuk pada buku terbitan Kementerian Pendidikan dan Kebudayaan serta sebagian ada juga guru yang melengkapinya dengan buku terbitan lain. Adapun materi yang disampaikan, kendati tidak terlalu sering, guru sesekali misalnya, mengaitkan teori pendidikan Islam dengan tradisi budaya.

c. Metode yang digunakan guru dalam pelaksanaan pendidikan agama Islam meliputi metode discovery, project, problem solving adalah metode yang paling banyak sering digunakan oleh guru. Kendati demikian, beberapa metode lain, milsanya, diskusi, ceramah, jigsaw dan praktik juga termasuk yang kerapkali digunakan oleh guru.

2. Implikasi pelaksanaan pendidikan agama Islam terhadap antisipasi radikalisme keagamaan

a. Dari sisi tujuan; pelaksanaan pendidikan agama Islam masih bersifat normatif, yakni bahwa pelaksanaan tersebut masih sebatas mengajarkan agama Islam kepada peserta didik. Oleh karena Islam sebagai rahmatan lil alamin, sejatinya pendidikan agama Islam diberikan di sekolah haruslah lebih ditekankan pada perilaku hidup beragama. Karena itu, untuk mengantisipasi penguatan paham radikalisme keagamaan peserta didik di sekolah misalnya, hendaknya pelaksanaan pendidikan agama Islam tidak semata-mata bagaimana ajaran agama diberikan, namun juga bagaimana nilai-nilai kebersamaan, kebaikan dan nilai-nilai umum antara agama atau kelompok-kelompok tertentu dapat dikaji secara bersama untuk kemudian diaplikasikan.

b. Dari sisi materi; penggunaan bahan ajar buku terbitan Pemerintah Republik Indonesia, yakni melalui Kementerian Pendidikan dan Kebudayaan mengindikasikan bahwa materi-materi yang tersaji atau yang akan disampaikan oleh guru setidaknya sudah melewati proses tahapan seleksi dan editing yang sangat ketat. Artinya, kecenderungan adanya materi dalam buku tersebut yang bersifat anomali dengan prinsip perilaku hidup beragama dan 
atau berkembangnya paham radikalisme keagamaan menjadi relatif minim untuk mengatakan tidak ada, ditemukan. Di sisi lain, mengintegraasikan penyampaian materi-materi pendidikan agama Islam dengan materi-materi lain misalnya, materi yang berhubungan dengan semangat ukhuwah islamiyah, insaniyah dan wathoniyah menjadi hal yang niscaya dilakukan oleh guru pendidikan agama Islam.

c. Dari sisi metode; penggunaan metode yang menekankan pada pendekatan student oriented dari beberapa metode yang biasa dipraktikkan guru pendidikan agama Islam, telah menunjukkan bahwa pola-pola indoktrinisasi perlahan sejatinya sudah mulai dikurangi. Artinya, sel-sel dari penyebaran pemahaman radikalisme keagamaan secara bertahap sudah dapat diminimalisir. Karena sesungguhnya, proses indoktrinisasi pemahaman radikalsime keagamaan dalam bentuk ceramah khususnya, dianggap cukup efektif pengaruh penyebarannya. 
Pendidikan Agama Islam dan Antisipaasi Radikalisme Keagamaan

\section{DAFTAR PUSTAKA}

Ahyar, Muzayyin, 2015, "Membaca Gerakan Islam Radikal dan Deradikalisasi Gerakan Islam” Walisongo, Vol. 23 No. 1.

Ali, Muhammad, tt, Kamus Bahasa Indonesia Modern, Jakarta: tp.

Arikunto, Suharsimi, 1990, Prosedur Penelitian: Suatu Pendekatan Praktik, Yogyakarta: Rineka Cipta.

Azra, Azyumardi, 1993, "Memahami gejala Fundamentalisme”, 'Ulumul Qur'an, Vol. 4, No 3.

----, 1996, Pergolakan Politik Islam: Dari Fundamentalisme, Modernisme Hingga PostModernisme, Jakarta: Paramadina.

Bakker, Anton, 1992, Metode Penelitian Filsafat, Yogyakarta: Kanisius.

Bangka Pos, Ini Alasan Kepolisian Tak Tahan Pemuda Balunijuk yang Mengbina Presiden Jokowi, bangka.tribunnews.com., diakses tanggal 14 September 2018

Bungin, Burhan, 2010, Metode Penelitian Kualitatif, Jakarta: Rajawali Pers.

el-Fadl, Khaled Abou, 2004, Atas Nama Tuhan: Dari Fikih Otoriter ke Fikih Otoritatif, terj. R. Cecep Lukman Yasin, Jakarta: PT. Serambi Ilmu Semesta.

Irwanto, 2006, Focussed Group Discussion, Jakarta: Yayasan Obor Indonesia.

Kartodirdja, Kartono, 1992, "Ratu Adil”, Sinar Harapan, Jakarta.

Koentjaraningrat, 1997, Metode-Metode Penelitian Masyarakat, Jakarta: Gramedia.

Krathwohl, David R., 1964, Taxonomy of Educational Objectives: Handbook II, Affective Domain, New York: David McKay.

Kusmanto, Thohir Yuli. dkk, 2015, "Dialektika Radikalisme dan Anti Radikalisme di Pesantren”, Walisongo, Vol 23 No. 1.

Madjid, Nurcholish, 1995, Pintu-pintu Menuju Tuhan, Jakarta: Paramadina.

Miles and Huberman, 1994, Qualitative Data Analysis, 2nd ed., California: SAGE Publications.

Moleong, Lexy J, 2005, Metode Penelitian Kualitatif, Bandung: Remaja Rosdakarya.

Munip, Abdul, 2012, "Menangkal Radikalime Agama di Sekolah", Jurnal Pendidikan Islam, Vol. 1, No. 2.

Nasution, Harun, 1995, Islam Rasional, Bandung: Mizan.

Nawawi, Hadari, 1983, Metode Penelitian Bidang Sosial, Yogyakarta: Gadjah Mada University Press.

Pals, Daniel L., 2001, Seven Theories of Religion, New York: Oxford University Press.

Partanto, Pius A. dan al-Barry, M. Dahlan, 1994, Kamus Ilmiah Populer, Surabaya: Arkola.

Poerwadaminta, 1986, Kamus Umum Bahasa Indonesia, cet. Ke-9, Jakarta: Balai Pustaka.

Rokhmad, Abu, 2012, "Radikalisme Islam dan Upaya Deradikalisasi Paham Radikal”, Jurnal Walisongo, Vol. 20, No. 1.

Scientia: Jurnal Hasil Penelitian, Vol. 4, No. 1 (2019) | 99 
Wahyudin Noor

Salim, Agus, 2006, Teori dan Paradigma Penelitian Sosial, Yogyakarta: Tiara wacana.

Samani, Muchlas dan Hariyanto, 2011, Konsep dan Model Pendidikan Karakter, Bandung: Rosda.

Shadily, Hasan, 1984, Ensiklopedi Indonesia, Jakarta: Ichtiar Baru-Van Hoeve.

Sutrisno Hadi, 1984, Metode Research III, Yogyakarta: Yayasan Penerbit Fakultas Psikologi UGM.

Tim Penyusun, 1988, Kamus Besar Bahasa Indonesia, cet. Ke-1, Jakarta: Balai Pustaka.

Turmudzi, Endang. dkk, 2004, Islam dan Radikalisme di Indonesia, Jakarta: LIPI Press.

van Bruinessen, Martin, 1994, NU: Tradisi, Relasi-relasi Kuasa, Pencarian Wacana Baru, terj. Farid Wajidi, Yogyakarta: LkiS.

Yunanto, S. dkk, 2003, Gerakan Militan Islam di Indonesia dan di Asia Tenggara, Jakarta: The Ridep Institute. 